\title{
Rừng trồng giúp phục hồi môi trường hiệu quả
}

\author{
- sciencevietnam $\leftleftarrows$ Khoa học lý thú (1) August 20,2021
}

SSHPA (20-08-2021) — Trồng rừng là một phương pháp quen thuộc để con người có thể cải tạo môi trường xanh. Tuy nhiên, vấn đề thực tế không thẳng và đơn giản như chúng ta nghĩ.

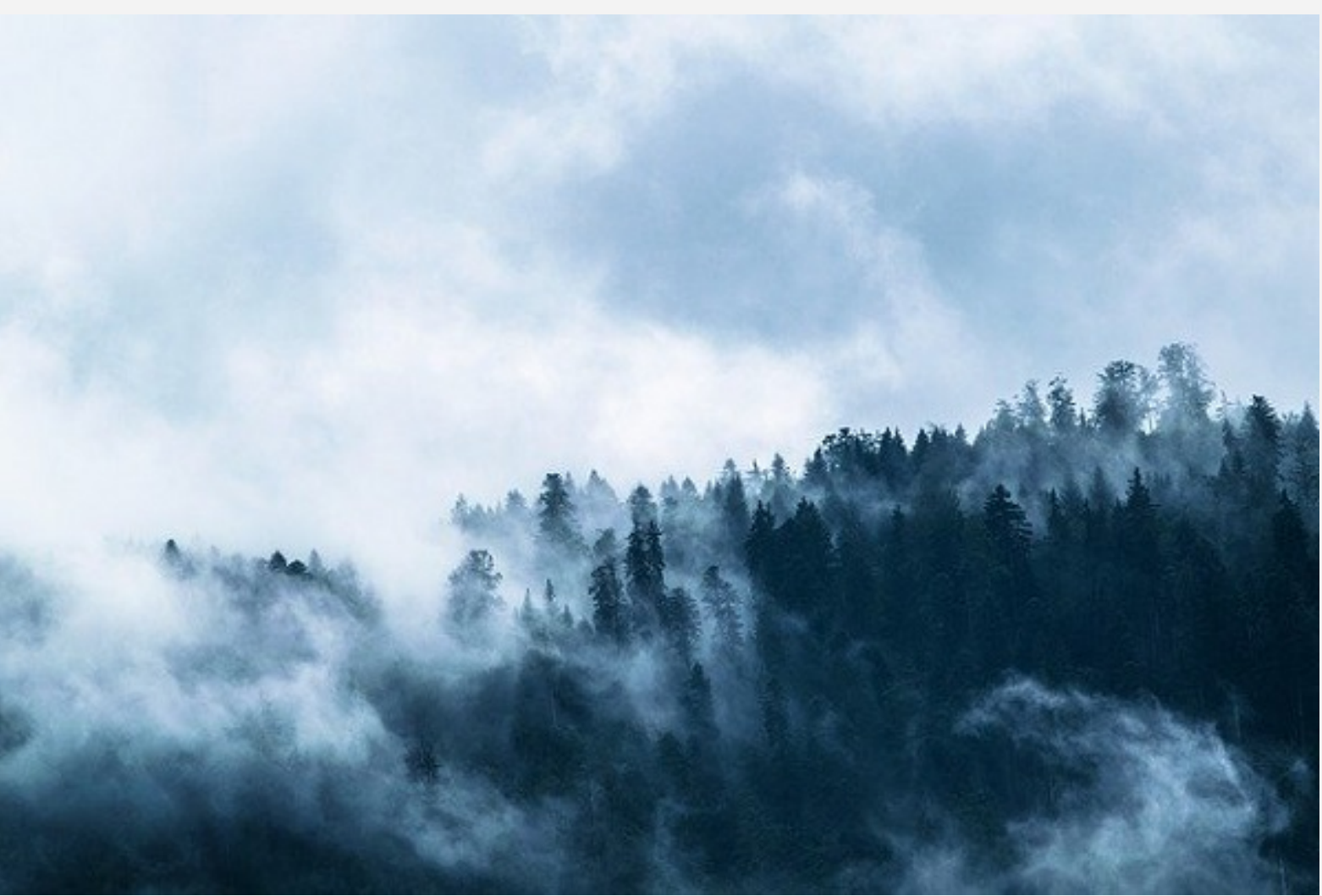

(Nguồn: Image by LUM3N from Pixabay)

Tại các vùng vĩ độ giữa $\left(23^{\circ} 26^{\prime 2} 22^{\prime \prime}\right.$ và $66^{\circ} 33^{\prime} 39^{\prime \prime}$ bắc, và $23^{\circ} 26^{\prime 2} 22^{\prime \prime}$ và $66^{\circ} 33^{\prime} 39^{\prime \prime}$ nam), các nhà nghiên cứu có phần băn khoăn vì hiệu quả môi trường thực sự của việc trồng cây. Rừng hấp thụ bức xạ mặt trời nhờ vào suất phản chiếu (albedo) thấp (tức khả năng phản xạ ánh sáng mặt trời của bề mặt). Nếu tại các vùng nhiệt đới, quá trình hấp thụ $\mathrm{CO} 2$ bởi thảm thực vật dày quanh năm giúp cân bằng suất phản chiếu thấp. Tuy nhiên, các nhà chuyên môn lo ngại lượng nhiệt bị mặt trời giữ lại sẽ xóa bỏ lượng CO2 trong không khí, làm giảm hiệu quả làm mát của cây cối tại các vùng ôn đới.

Tuy nhiên, dựa trên dữ liệu vệ tinh và các mô hình tính toán, nghiên cứu Cloud cooling effects of afforestation and reforestation at midlatitudes [1] mới đây trên tạp chí PNAS đã cho thấy chúng ta không cần quá lo lắng. Thực tế, mây—một yếu tố rất quan trọng—đã bị bỏ qua. Kết quả nghiên cứu cho thấy các đám mây dày đặc và rừng giúp quá trình làm mát bề mặt Trái Đất hiệu quả hơn rất nhiều.

Điều này cho thấy việc cần làm hiện tại là các chiến lược trồng cây gây rừng, và khai thác tài nguyên rừng thật tốt. Văn hóa xanh của các doanh nghiệp, đặc biệt là những công ty khai thác rừng và khoáng sản, sẽ đặc biệt quan trọng để gia tăng hiệu quả của việc trồng rừng [2,3].

\section{Tài liệu tham khảo:}

[1] Cerasoli S, Yin J, \& Porporato A. (2021). Cloud cooling effects of afforestation and reforestation at midlatitudes. Proceedings of the National Academy of Sciences, 118(33). 
[2] Vuong QH, et al. (2021). Identifying the moral-practical gaps in corporate social responsibility missions of Vietnamese firms: An event-based analysis of sustainability feasibility. Corporate Social Responsibility and Environmental Management, 28(1), 30-41.

[3] Vuong QH. (2021). The semiconducting principle of monetary and environmental values exchange. Economics and Business Letters, 9(3), 284-290.

(1) Last modified: $8 / 22 / 20213: 50$ PM (2) Views: 8 o 0

\section{Bài liên quan:}

- Sự tiến hóa biểu cảm khuôn mặt của các chú chó gắn liền với loài người

- Hoàng gia Nhật Bản - khi nhà vua làm nghiên cứu khoa học

- Chiến tranh, chứ không phải nông nghiệp, có ảnh hưởng quan trọng đối với cháy rừng vào cuối Thế Toàn Tân (the Holocene) tại Bắc Việt Nam

- Quỹ NAFOSTED và các công bố trên hệ thống xuất bản của Nature, Science: Quả ngọt đầu mùa

- Đầu tư vào nghiên cứu khoa học cơ bản của Trung Quốc lên tới 34 tỉ USD vào năm 2020

\section{Ý kiến bạn đọc (0):}

Comment

Gửi bình luận

(c) 2018 - 2021 EASE Vietnam SciComm System. All rights reserved. Powered by Vuong \& Associates. Built to serve the social sciences and humanities. 